Omni-Akuatika, 14 (3): 10-17, 2018
ISSN: 1858-3873 print / 2476-9347 online
Research Article
journal homepage: http://ojs.omniakuatika.net

\title{
Distribution of Batillaria Zonalis (Mollusca : Gastropoda) on Avicennia Marina (Forsk.) Vierh in The Coast of Banggi, Rembang, Central Java
}

\author{
Dafit Ariyanto ${ }^{1,2^{\star}}$, Dietriech Geoffrey Bengen ${ }^{2}$, Tri Prartono ${ }^{2}$, Yusli Wardiatno ${ }^{3}$ \\ ${ }^{1}$ Department of Aquaculture, Agricultural Faculty, Asahan University, Jl Ahmad Yani Kisaran, \\ North Sumatera 21224, Indonesia \\ ${ }^{2}$ Department of Marine Science and Technology, Marine Science and Fisheries Faculty, Bogor \\ Agricultural University, Jl Rasamala Bogor 16680, Indonesia
${ }^{3}$ Department of Aquatic Resources Management, Marine Science and Fisheries Faculty, Bogor \\ Agricultural University, Jl Rasamala Bogor 16680, Indonesia \\ Corresponding author : dafitariyanto676@gmail.com
}

Received 24 July 2018; Accepted 25 September 2018; Available online 30 November 2018

\begin{abstract}
Mangroves prove a habitat for Batillaria zonalis as nursery ground, feeding ground and reproductive ground. This research was conducted from September 2016 - August 2017 . The aim of the research was to determine the spasial and temporal pattern based on mangrove zone and environmental characteristics. The gastropod samples were taken by using square transect sized $25 \mathrm{~cm} \times 25 \mathrm{~cm}$. The spatial analyses was done by using transect $10 \mathrm{~m} \times 10 \mathrm{~m}$. The gastropods and environmental characteristics were analyzed using Principal Component Analysis (PCA). The results showed organic matter (0.92), total phosphorus (0.92), dust (0.86), clay $(0.86)$, conductivity $(0.83)$, temperature $(0.69)$, and redox potential $(0.90)$ that significant changes in gastropod assemblages were primarily due to changes in the water quality and season. Correlation between gastropod and physico-chemical parameters in A. marina revealed significant relationship with gastropod $B$. zonalis distribution.
\end{abstract}

Keywords: Batillaria zonalis, mangrove, mollusca, water quality, Banggi Coast

\section{Introduction}

Banggi coast is located on the North Coast of Banggi Coast in the North Coast of Java located in Rembang District, Central Java, Indonesia (6'30-7'06 S and 111'00 111'30 E). Banggi Coast has a dominant mangrove The Banggi coast in Rembang, Central Java is fringed by various species of mangrove such as Rhizophora mucronata Lam., Rhizophora apiculata Blume, Rhizophora stylosa Griff., Avicennia marina (Forssk.) Vierh., and Sonneratia alba Sm (Ariyanto et al., 2018). Mangrove $A$. marina has a distribution pattern and growth that related on sediment factor and tide level (Ahmed and Kheder, 2007). Mangrove ecosystem proved a nursery ground, feeding ground and reproductive ground the marine organisms. The existence of mangrove can be used gastropod as an ecological funtion associtaed with various proceses (Bremner et al., 2006 ).

B. zonalis (Potamididae) can be found on on muddy substrate of mangrove and plays an important role on organic cycle on mangrove ecosystem (Kamimura and Tsuchiya, 2004). The presence of antropogenic disorders, the development of aquaculture ponds and the expansion of settlements resulted in changes in the mangrove ecosystem. These chages can alter the stability of mangrove structures, indivual pressures on distribution and organism abundance (Fondo and Martens, 1998; Beasly et al., 2005) and an important process in the food chain (Giesen et al., 2007). Based on this information, $B$. zonalis in shandy shore (Chan and Chan, 2005); feeding behavior (Kamimura and Tsuchiya, 2004); Diversity of Shell Colour (Miura et al., 2007) it is still minimal information about the distribution pattern of gastropod $B$. zonalis on the environmental characteristics. This research aims to determine spatial and temporal pattern of gastropods $B$. zonalis based on the environmental characteristics on $A$. marina zone in Banggi Coast, Rembang, Central Java, Indonesia. 


\section{Material And Methods}

\subsection{Study Seat}

The research was conducted on September 2016 - July 2017 at Banggi Coast, in Rembang, Central Java, Indonesia (6'42'5 $S$ and 111'23'16 E). The research location was divided into 3 zones of observations such as : seaward zone, middle zone, and landward zone.

\subsection{Sample collection}

The Gastropod samples was taken by using six times square transect sized $25 \mathrm{~cm} x$ $25 \mathrm{~cm}$, placed inside transect sized $10 \mathrm{~m} x$ $10 \mathrm{~m}$. The sampling was conducted in September and November 2016, January, March, May and July 2017. The gastropod was located over sediment (in how many $\mathrm{cm}$ of deoth?) and taken when the sea was at the low tide. The gastropod sample found in this research was identified morphologically as $B$. zonalis by using Dharma (1988). The gastropod sample identified morphologically. Length measurement was done by using digital caliper with $0.1 \mathrm{~mm}$ accuracy. The gastropods samples' species abundance was measured (Brower et al., 1990) and classified of length on each transect and time taken. Length frequency distribution allow to determine the size group of gastropods $B$. zonalis by looking at it's frequency modus of shell length.

\subsection{Physico-chemical Parameters}

The water quality measurements in each zone were : temperature, salinity, $\mathrm{pH}$, DO, redox potential and conductivity by using water quality meter. Each zone was measured six times included September and November 2016, January,, March, and May 2017. Analysis of sediment samples was conducted at the Aquatic Productivity and Environment Laboratory, Bogor Agricultural University, which included organic materials, soil texture, total nitrogen and total phosphorus. Measurement of organic matter content was done by Walkey-Black method, while soil texture measurement was done by pipette method, and total nitrogen and total phosphorus used a spectrophotometry (Pansu and Jacques 2003; APHA 2012).

\subsection{Data Analysis}

The statistical analysis component (PCA) was used in order to determine the analysis of gastropod distribution patterns based on environmental characteristics. The main component analysis displayed the data in graphical form, the data matrix, consisting of research zone as individual (line) and environmental variable as well as number of $B$. zonalis (column). This analysis used Xlstat 2016 program.

\section{Results And Discussion}

\subsection{Gastropoda abundance}

Figure 1 shows the abundance of gastropods $B$. zonalis in Coast of Banggi, Rembang, Central Java. Abundance of gastropods $B$. zonalis was obtained by total of gastropod type is 503 ind $/ \mathrm{m}^{2}$ that consisted of zone $A\left(141 \pm 80 \mathrm{indv} / \mathrm{m}^{2}\right)$, zone $B\left(110 \pm 34\right.$ ind indv $\left./ \mathrm{m}^{2}\right), C$ zone $(57 \pm$ $34 \mathrm{ind} / \mathrm{m}^{2}$ ). Zone $A$ based on observations of the highest time of May 2017 (53 \pm 14 ind $\left./ \mathrm{m}^{2}\right)$ and the lowest in June 2017 (0 ind $/ \mathrm{m}^{2}$ ). The abundance of zone $B$ based on observations of the highest time of January $2017\left(41 \pm 14\right.$ ind $/ \mathrm{m}^{2}$ ) and the lowest in May 2017 was not found. The abundance of $C$ zone gastropods based on observations of the highest time of September $2016(41 \pm$ $15 \mathrm{ind} / \mathrm{m}^{2}$ ) and the lowest in November 2016, January 2017, May 2017 and June 2017. The overall abundance of high gastropods in zone $A$ indicates from tidal. Zone $\mathrm{C}$ has the lowest abundance due to the presence of a river in location, causing $B$. zonalis to be uncomfortable in its life processes including living, feeding and reproducing. Gastropods B. zonalis has the lowest abundance are caused by water fluctuations and the occurrence of high rainfall during observation. Intertidal zones fluctuate during periods of tidal fluctuations, drying and osmotic pressure on a regular basis that affect habitat and mortality for organisms. High temperatures result in high drying and mortality processes caused by overheating (Sokolova and Berger, 2000). Skilleter and Warren (2000) suggest the impacts were caused by human activity can cause changes in tidal dynamics and subsequently affect the distribution of leaves in the substrate and result in abundance of gastropods. 


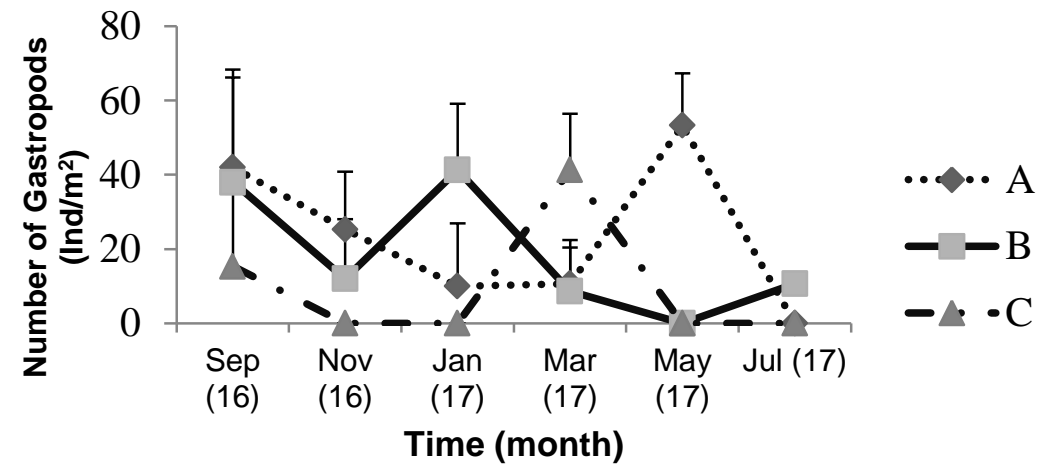

Abbreviations: $\mathrm{A}=$ seaward $\mathrm{B}=$ middle zone, $\mathrm{C}=$ landward zone

Figure 1. The abundance of gastropod Batillaria zonalis in Coast of Banggi, Rembang, Central Java

\subsection{Distribution of Lenght, Weight, and Width in B. zonalis}

Table 1 shows distribution of the length, weight, and width in Batillaria zonalis at Coast of Banggi, Rembang, Central Java. This study shows differences in each zone and time. The highest longest measure was in the seaward zone $(27.91 \pm 2.48 \mathrm{~mm})$ on January 2017 while the lowest was the middle zone B $(20.41 \pm 2.91 \mathrm{~mm})$ on September 2016. The highest width measure was the lowest in the middle zone $(11.55 \pm 1.71 \mathrm{~mm})$ and July 2017 . The highest weight was in the middle zone (2.12 $\pm 0.15 \mathrm{~g})$ and June 2017 and the lowest in the middle zone $(1.03 \pm 0.25 \mathrm{~g})$ and
September 2016. The overall results of the length, width and weight of gastropods $B$. zonalis indicated highly specified zone and time. These suggested that the rainy season (January 2017) please provide th e data of rain can supply a food, so it can be used to growth in lenght. Weight and width were more dominant in the middle zone because the zone was efective condition from the effect of environmental changes such as the influence of sea water and land effects trough the flow of fresh water during the reproductive period. (Chan and Chan, 2005) reported that the reproductive season of $B$. zonalis occurs between July - October with gastropod put eggs on the sand surface.

Table 1. Gastropod Batillaria zonalis Distribution of Lenght, Weight, and Width of in Coast of Banggi, Rembang, Central Java.

\begin{tabular}{lllllll}
\hline Parameters & Sept 2016 & Nov 2016 & Jan 2017 & Mar 2017 & May 2017 & July 2017 \\
\hline A & & & & & & \\
Lenght $(\mathrm{mm})$ & $23.90 \pm 2.41$ & $24.5 \pm 3.9$ & $27.91 \pm 2.48$ & $24.47 \pm 4.36$ & $24.04 \pm 2.5$ & - \\
Weight $(\mathrm{g})$ & $1.15 \pm 0.23$ & $1.36 \pm 0.38$ & $1.74 \pm 0.38$ & $1.88 \pm 0.35$ & $1.31 \pm 0.32$ & - \\
Width $(\mathrm{mm})$ & $7.86 \pm 0.82$ & $10.35 \pm 66$ & $8.86 \pm 0.41$ & $10.70 \pm 0.53$ & $10.18 \pm 1.23$ & - \\
B & & & & & & \\
Lenght $(\mathrm{mm})$ & $20.41 \pm 2.91$ & $24.46 \pm 4.18$ & $25.93 \pm 3.19$ & $26.29 \pm 2.62$ & - & $27.28 \pm 2.02$ \\
Weight $(\mathrm{g})$ & $1.03 \pm 0.25$ & $1.5 \pm 0.3$ & $1.62 \pm 0.32$ & $1.94 \pm 0.45$ & - & $2.12 \pm 0.15$ \\
Width $(\mathrm{mm})$ & $6.69 \pm 2.11$ & $11.17 \pm 2.62$ & $8.84 \pm 0.63$ & $11.01 \pm 0.65$ & - & $11.55 \pm 1.71$ \\
C & & & - & & & - \\
Lenght $(\mathrm{mm})$ & $24.01 \pm 1.63$ & - & - & $25.17 \pm 2.6$ & - & - \\
Weight $(\mathrm{g})$ & $2.25 \pm 0.22$ & - & - & $1.70 \pm 0.25$ & - & - \\
Width $(\mathrm{mm})$ & $8.04 \pm 1.75$ & - & - & $9.88 \pm 0.97$ & - & \\
\hline
\end{tabular}




\subsection{Frequency Distribution of Lenght in B. zonalis}

Figure 2 shows the frequency distribution of lenght in $B$. zonalis in Coast Banggi Rembang Central Java. Frequency distribution of gastropod length was needed to know the distribution of size dominance during research with different zone. Zone $\mathrm{A}$ (seaward) of dominant length was 24.02 -
$26.50 \mathrm{~mm}\left(43 \mathrm{ind} / \mathrm{m}^{2}\right)$, zone B (midlle zone) of dominant length was $25.30-28.30 \mathrm{~mm}$ (25 ind $/ \mathrm{m}^{2}$ ), and $\mathrm{C}$ (landward) dominant size was $24.78-26.81 \mathrm{~mm}$ (24 ind / m2). The highest overall dominant length in zone $\mathrm{B}$. It indicates that zone $B$ is the most comfortable zone for $B$. zonalis its life cycle. Zone $B$ is not directly related to the tide of sea water.

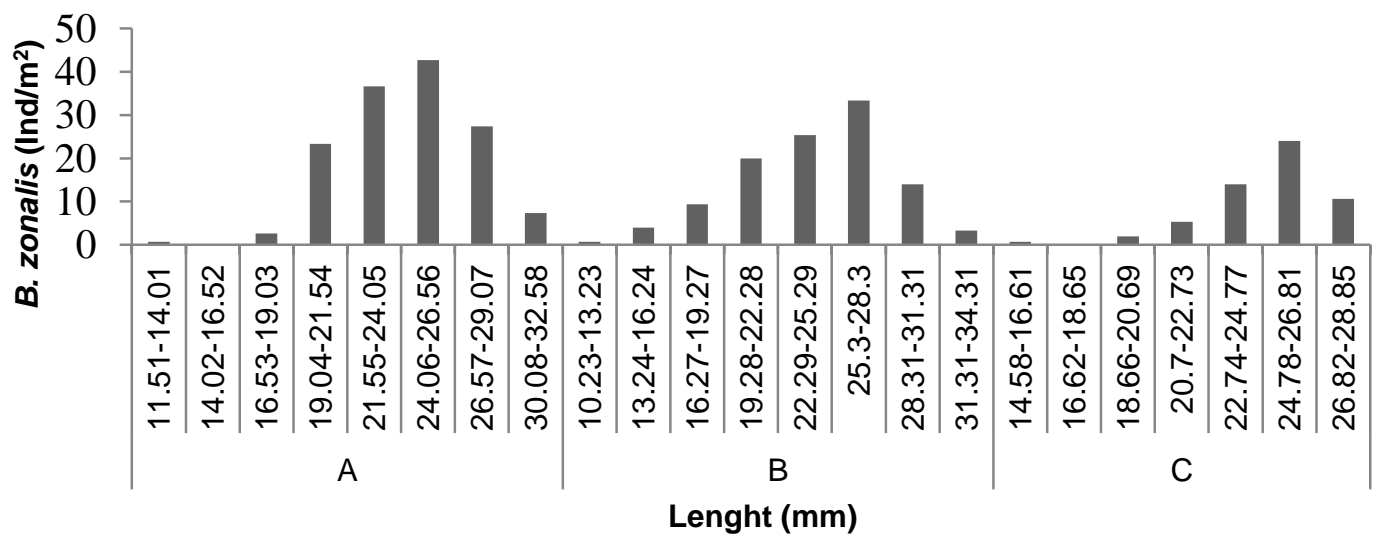

Figure 2. Frequency distribution of gastropod B. zonalis in A. marina in Coast of Banggi, Rembang, Jawa Tengah, Indonesia.

\subsection{Physico-chemical Parameter Sediment Condition}

Table 2 shows sediment conditions including organic matter, total nitrogen, total phosphorous and substrate type in Coast of Banggi, Rembang Central, Java. The content of organic material in zone A (1.96 \pm $1.81 \%)$, zone B (1.97-1.26\%), zone C (1.47 -
$0.96 \%)$. The total nitrogen content of zone A $(0.44 \pm 0.39)$, zone B $(0.98 \pm 1.47)$, and zone $C(0.45-0.53)$ and phosphorus content of zone $\mathrm{A}(0.68 \pm 0.36)$, zone $\mathrm{B}(0.88 \pm 0.81)$ and zone $C(0.57 \pm 0.21)$. The substrate composition of this study shows the most dominant dust substrate compared to sand and clay from the various zones $A, B$, and $C$

Table 2. Sediment conditions in Coastal Banggi Rembang Central Java

\begin{tabular}{clcccccc}
\hline \multirow{2}{*}{ Zone } & \multirow{2}{*}{ Months } & Organic & Phosphor & Total & \multicolumn{3}{c}{ Sediment (\%) } \\
\cline { 6 - 8 } & Matter (\%) & $(\%)$ & Nitrogen (\%) & Sand & Dust & Clay \\
\hline \multirow{2}{*}{ A } & Sept 2016 & 0.94 & 0.36 & 0.06 & 0.02 & 97.13 & 2.85 \\
& Jan 2017 & 0.89 & 0.57 & 0.85 & 0.65 & 96.66 & 2.36 \\
& July 2017 & 4.05 & 1.11 & 0.41 & 0.27 & 95.14 & 4.59 \\
\hline \multirow{2}{*}{ B } & Sept 2016 & 0.61 & 0.27 & 0.03 & 0.02 & 95.67 & 4.31 \\
& Jan 2017 & 3.09 & 1.8 & 2.69 & 0.66 & 96.44 & 3.9 \\
& July 2017 & 2.21 & 0.58 & 0.24 & 0.65 & 96.63 & 6.72 \\
\hline \multirow{2}{*}{ C } & Sept 2016 & 0.77 & 0.33 & 0.04 & 0.02 & 96.35 & 3.63 \\
& Jan 2017 & 1.08 & 0.72 & 1.06 & 6.65 & 90.91 & 3.44 \\
& July 2017 & 2.57 & 0.68 & 0.27 & 0.10 & 96.05 & 3.85 \\
\hline
\end{tabular}

Sediments characteristics play a major role in mangrove ecosystem on the arrangement of benthic communities with other physicochemical variables. gastropode mode of life was epi fauna Safahieh et al., (2012) reported the distribution of macrobenthos were primarily determined by grain size of sediment, salinity, and water 
availability. Physical fluctuations may decline the abundance of benthic species (Kathiresan and Bingham, 2001). Texture of sediments determine gastropods in foodsearch strategies by adjusting for sediment types (Zhuang et al., 2004). Davis et al., 2003 states that the more soft in the sediment substrate becomes higher in the organic matter content.

\subsection{Water quality Parameters}

Table 3 shows the distribution of water quality parameters at various zone.
Zone $A$ has DO $(7 \pm 1.74 \mathrm{mg} / \mathrm{l})$, salinity $(28.11 \pm 6.17 \mathrm{psu}), \mathrm{pH}(6.46 \pm 2.2)$, temperature $\left(30 \pm 1.32{ }^{\circ} \mathrm{C}\right)$, redox potential $(47.1 \pm 26.96 \mathrm{mV})$ and conductivity $(43.35 \pm$ $22.58 \mathrm{mS} / \mathrm{cm})$. Zone B has DO value $(6 \pm$ $0.93 \mathrm{mg} / \mathrm{l})$, salinity $(30.05 \pm 4.64 \mathrm{psu}), \mathrm{pH}(8$ $\pm 0.15)$, temperature $\left(32.36 \pm 1.5^{\circ} \mathrm{C}\right)$, redox potential $(54.85 \pm 46.28 \mathrm{mV})$ and conductivity $(49.07 \pm 12.81 \mathrm{mS} / \mathrm{cm})$. Zone C has DO $(5.66 \pm 1.55 \mathrm{mg} / \mathrm{l})$, salinity $(28.9 \pm 4$ psu), $\mathrm{pH}(7.8 \pm 0.32)$, temperature $(29.48 \pm$ $\left.1.5^{\circ} \mathrm{C}\right)$, redox potential $(-36.71 \pm 89.33 \mathrm{mV})$ and conductivity $(53 \pm 29.33 \mathrm{mS} / \mathrm{cm})$.

Table 2. Water Quality Parameters in Coast Banggi, Rembang, Central Java, Indonesia

\begin{tabular}{llllllll}
\hline Zone & \multicolumn{1}{c}{ Parameters } & Sep16 & Nov 2016 & Jan 2017 & Mar 2017 & May 17 & Jul 2017 \\
\hline \multirow{4}{*}{ A } & DO (mg/l) & 5.69 & 8.73 & 7.6 & 6.6 & 8.9 & 4.5 \\
& Salinitay $(\mathrm{psu})$ & 27 & 26 & 30 & 25.2 & 32.9 & 25.2 \\
& pH & 7.46 & 8.35 & 3.84 & 7.15 & 3.98 & 8.03 \\
& Suhu $\left({ }^{\circ} \mathrm{C}\right)$ & 32.7 & 30.1 & 30.2 & 33.6 & 30.8 & 32.6 \\
& Redox Potential $(\mathrm{mV})$ & 88.4 & 39 & 48.5 & 10.9 & 64.5 & 31.3 \\
& Conduktivity $(\mathrm{mS} / \mathrm{cm})$ & 66.1 & 20.6 & 55.3 & 56.6 & 9.78 & 51.7 \\
\hline \multirow{3}{*}{ B } & DO (mg/l) & 6.05 & 5 & 7.66 & 6.08 & 5.9 & 5.23 \\
& Salinitay $(\mathrm{psu})$ & 28.5 & 25 & 30 & 25.7 & 33.2 & 30.9 \\
& pH & 7.9 & 8.18 & 7.0 & 7.93 & 8.07 & 8.13 \\
& Suhu $\left({ }^{\circ} \mathrm{C}\right)$ & 32 & 32.7 & 30.1 & 31.4 & 30.7 & 31.3 \\
& Redox Potential $(\mathrm{mV})$ & 78.1 & 49.2 & 37.1 & -21.2 & 69.1 & 116.8 \\
& Conduktivity $(\mathrm{mS} / \mathrm{cm})$ & 67.3 & 33.2 & 54.2 & 35.3 & 51.7 & 52.7 \\
\hline \multirow{2}{*}{ DO (mg/l) } & 4.26 & 4.01 & 7.89 & 7.08 & 5.83 & 4.86 \\
& Salinitay $(\mathrm{psu})$ & 30 & 29 & 30 & 25.05 & 30.2 & 24.1 \\
& pH & 7.49 & 7.43 & 7.94 & 7.92 & 7.73 & 8.29 \\
& Suhu $\left({ }^{\circ} \mathrm{C}\right)$ & 28 & 30.3 & 30.1 & 20.2 & 28.6 & 29.7 \\
& Redox Potential $(\mathrm{mV})$ & -103.7 & 7.4 & -86.1 & -143.9 & 11.52 & 94.5 \\
& Conduktivity $(\mathrm{mS} / \mathrm{cm})$ & 54.5 & 11.14 & 54.2 & 103.1 & 47.3 & 50.9 \\
\hline
\end{tabular}

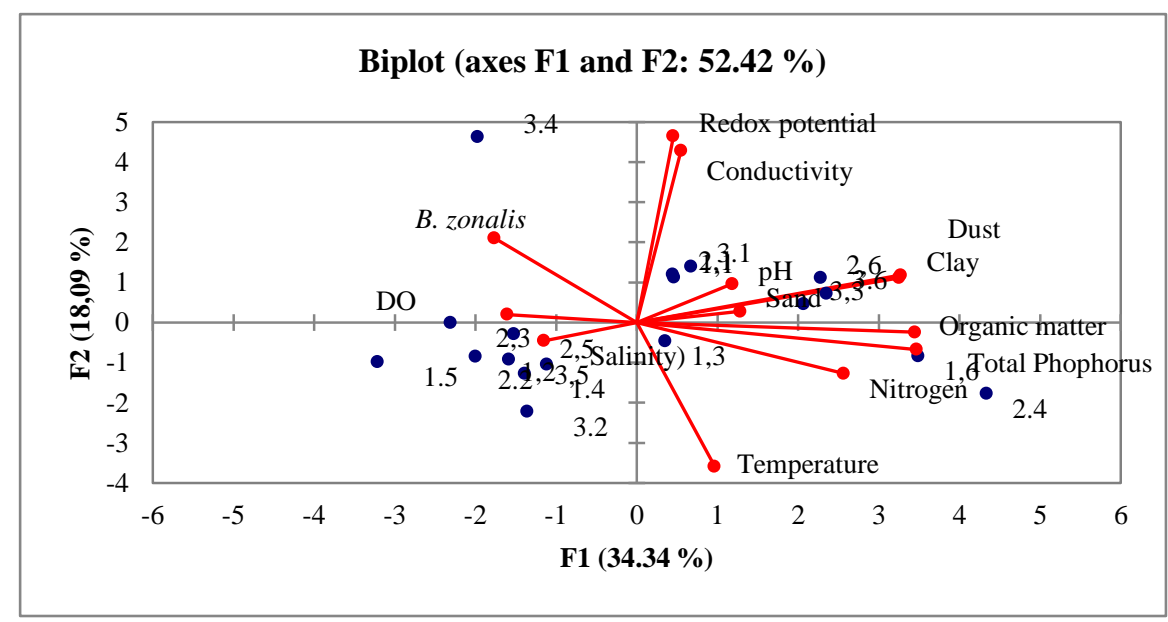

Figure 3. Principal component analysis (PCA) for relationship $B$. zonalis and physico-chemicall characteristic in Coast Banggi Rembang Central Java Indonesia 


\subsection{Distribution of $B$. zonalis in physico-} chemical Characteristics

Figure 3. shows distribution of $B$. zonalis in environmental characteristic in Coast of Bangg, Rembang, Central Java. The Principal Component Analysis result of total F1 and F2 showed 52.42 consisted of F1 (34.34\%) and F2 (18.09\%). Based on factor loading showed organic matter (0.92), total phosphorus (0.92), dust $(0.86)$, clay $(0.86)$, conductivity (0.83), temperature (0.69), and redox potential (0.90).

Gastropods are closely related to water quality conditions in the mangrove ecosystem such as salinity, oxygen, temperature and nutrient effects (Swami et al., 2000; Jayaraj, 2007). Gastropods have many adaptations to survive in various environmental conditions, such as survive at extreme temperatures and salinity (Shumway and Marsden 1981; Miura et al., 2007. Please add some newest references. Salinity is a major determinant of distribution patterns and abundance. Substrate conditions such as texture and sediment composition have an effect on gastropod . Mangrove can act well as an absorbent accumulation of organic matter and can utilize in coastal areas (Dittmar et al., 2006). Sharma (1986) ; Garg et al., (2009) documented that some molluscs can survive in very low oxygen conditions. The main factor that affects the distribution and diversity of animals include the structure and composition of mangrove vegetation (Zakaria and Rajpar, 2015), physical and predation pressure (Peng et al., 2017). Gastropod has a tolerance capabilities for difficult conditions in the mangrove ecosystem (Hogarth, 2015) and gastropods have a high abundance and distribution in mangrove ecosystem because of their movement characteristics (Kabir et al., 2014). Gastropods are poorly developed in mangrove forests that were dominated by sandy substrates with poor food conditions, whereas adult gastopods may have grown in muddy mangrove forests as rich sources of food (Nishihira et al., 2002).

\section{Conclusion}

Distribution of $B$. zonalis in environmental characteristic in Coast of Banggi, Rembang, Central Java such as organic matter, total phosphorus, dust texture, clay texture, conductivity, temperature, and redox potential.
Abundance of gastropods $B$. zonalis was obtained by zone $A\left(141 \pm 80 \mathrm{indv} / \mathrm{m}^{2}\right)$, zone $B\left(110 \pm 34\right.$ ind indv $\left./ \mathrm{m}^{2}\right), C$ zone $(57 \pm$ $\left.34 \mathrm{ind} / \mathrm{m}^{2}\right)$.

\section{Acknowledgement}

The authors are thankful to Ministry of Research and Technology of Higher Education, Indonesia for providing BPPDN fellowship for pursuing PhD (2014-2018).

\section{References}

Ahmed, A. and A.A. Khedr. 2007. Zonation Pattern of Avicennia marina and Rhizophora mucronata along the Red Sea Coast, Egypt. World Application Science Journal 2(4): 283-288.

[APHA] American Public Health Association $22^{\text {st }}$ ed. 2012, Standard Methods for Examination of Water and Wastewater Metode 4500-N-Org-B (Macro Kjeldahl Method) dan 4500NH3-F (Manual Phenate Method).

Ariyanto D, Bengen DG, Prartono T, Wardiatno Y. 2018. Short Communication: The relationship between content of particular metabolites of fallen mangrove leaves and the rate at which the leaves decompose over time. Biodiversitas 19, 700-705.

Beasly, C.R., Fernandes, C.M. Gomes, C.P., Brito, B.A., Santos M.L., Tagliaro C.H. 2005. Molluscan diversity and abundance among coastal habitats of northern Brazil. Ecotropica 11, 9-20.

Bremner, J., Rogers, S.I., Frid, C.L.J. 2006. Matching biological traits to environmental conditions in marine benthic ecosystems. Journal of Marine System 60, 302-316.

Brower, J.E., Zar., J.H. Von Ende, C.N.. 1990. Field and laboratory methods for general ecology, third edition.Wm. C. Brown Publishers. Dubuque, lowa. pp 237.

Chan, D.H.L., and Chan. B.K.K. 2005. Effect of epibiosis on the fitness of the sandy shore snail Batillaria zonalis in Hong Kong. Marine Biology. 146, 695-705.

Davis, S.E., Corronado-Molina, C., D.L. Childers., Day, D.W. 2003. Temporally dependent $\mathrm{C}, \mathrm{N}$, and $\mathrm{P}$ dynamics associated with the decay 
of Rhizophora mangle L. leaf litter in oligotrophic mangrove wetlands of the Southern Everglades. Aquatic Botany 75, 199-215

Dharma, B. 1988. Siput dan Kerang Indonesia (Indonesian Shells). PT. Sarana Graha, Jakarta. 111 pp.

Dittmar, T., Hertkorn, N., Kattner, G., Lara, R.J. 2006. Mangroves, a major source of dissolved organic carbon to the oceans. Glob Biogeochemistry Cycles 20, 10-12

Fondo, E.N., and Martens, E.E. 1998. Effects of mangrove deforestation on macrofaunal densities, Gazi bay, Kenya. Mangrove and Salt Mars 2, 75-83.

Garg, R.K, Rao, R.J., Saksena, D.N. 2009. Correlation of molluscan diversity with physicochemical characteristics of water of Ramsagar reservoir. India. International Journal of Biodiversity and Conservation 6, 202-207.

Giesen, W. Wulffraat, S., Zieren, M., Scholten, L. 2007. Mangrove Guidebook for Southeast Asia. FAO Regional Office for Asia and the Pacific, Bangkok. Thailand.

Hogarth, P.J. 2015. The Biology of Mangroves and Seagrasses, third ed. Oxford University Press, Oxford, p. 304.

Jayaraj, K.A., Jayalakshmi, K.V. Saraladevi, K. 2007. Influence of environmental properties on macrobenthos in the northwest Indian shelf. Environmental Monitoring. and Assessment 127, 459-475.

Kabir, M., M. Abolfathi, A. Hajimoradloo, S. Zahedi, K, Kathiresan., and S. Goli.. 2014. Effect of mangroves on distribution, diversity and abundance of molluscs in mangrove ecosystem: a review. AACL 7(4) : 286-300.

Kamimura, S., and Tsuchiya, M. 2006. Effects of opportunistic feeding by the intertidal gastropods Batillaria zonalis and $B$. flectosiphonata on material flux on a tidal flat. Marine Ecology and Progress Series. 318, 203-211.

Kathiresan, K., and Bingham, L. 2001. Biology of mangroves and mangrove ecosystems. Advance and Marine
Biology. 40 : 82 -251Miura O., Syuhei Nishi S., Chiba S. 2007. TemperatureRelated Diversity Of Shell Colour In The Intertidal Gastropod Batillaria. Journal of Molluscan Studies 73, 235240.

Nishihira, M., Kuniyoshi, M., Shimamura, K. 2002. Size variation in Terebralia palustris (Gastropoda: Potamididae) of Iriomote Island, southern Japan, and its effect on some population characteristics. Wetland Ecology and Management 10, 243-247.

Pansu, M., and G. Jacques. 2003. Handbook of Soil Analysis Mineralogical, Organic, and Inorganic Methods. Verlag. Springer.

Peng, Y., Zhang, M., Lee, S.Y. 2017. Food availability and predation risk drive the distributional patterns of two pulmonate gastropods in a mangrovesaltmarsh transitional habitat. Marine and Environmental Research 130, 21-29.

Safahieh, A,. M.B. Nabavi, A, Vazirizadeh, M.T. Ronagh, R. Kamalifar. 2012. Horizontal zonation in macrofauna community of Bardestan mangrove Creek, Persian Gulf. World Journal of Fish Marine Science 4(2), 142-149.

Sharma, R.C. 1986. Effect of physicochemical factors on benthic fauna of Bhagirathi river, Garhwal Himalayas. Ind. Journal of Ecology 13, 133-137

Shumway, S.E., and Marsden, I.D. 1981. The combined effects of temperature, salinity and declining oxygen tension on oxygen consumption in the marine pulmonate Amphibola crenata (Gmelin). Journal of Experimental Marine Biology and Ecology 6 : 133146.

Skilleter, G.A., and Warren, S. 2000. Effects of habitat modification in mangroves on the structure of mollusc and crab assemblages Journal of Experimental Marine Biology and Ecology . 244 :107-129.

Sokolova, I.M., and Berger, V.Y. 2000. Physiological variation related to shell colour polymorphism in White Sea Littorina saxatilis. Journal of Experimental Marine Biology and Ecology 245, 1-23 
Swami, B.S., Suryawanshi, U.G., Karande, A. 2000. Water quality of Mumbai harbor, Indian. Journal of Marine Science 29, 111-115.

Zakaria, M., and M.N. Rajpar. 2015. Assessing the Fauna Diversity of Marudu Bay Mangrove Forest, Sabah, Malaysia, for Future Conservation. Diversity. 7, 137-148.

Zhuang, S., Zhang, M., Zhang, X., Wang, Z. 2004. The influence of body size, habitat and diet concentration on feeding of Laternula marilina Reeve. Aquacitc Research 35,622-628. 